\title{
An overview of the genus Quadrulella (Arcellinida: Hyalospheniidae) from Bulgaria, with description of Quadrulella deflandrei sp. nov.
}

\author{
Nikola Bankov, Milcho Todorov and Anna Ganeva \\ Institute of Biodiversity and Ecosystem Research, Bulgarian Academy of Sciences, \\ 1000 Sofia, Bulgaria
}

| Submitted March 31, $2021 \mid$ Accepted May 10, 2021 |

\begin{abstract}
Summary
All species of the genus Quadrulella recorded in Bulgaria are described morphologically and morphometrically and distributional data for them are provided. A new testate amoeba Quadrulella deflandrei sp. nov. isolated from Sphagnum mosses is described. The newly described species resembles $Q$. symmetrica in its general shape, but differs from it by about twice the size and significantly more and larger shell plates (maximum size $15-19 \mu \mathrm{m}$ in $Q$. deflandrei vs. $10-12 \mu \mathrm{m}$ in $Q$. symmetrica). On the other hand, $Q$. deflandrei has a similar size as $Q$. quadrigera and $Q$. squtellata but can be easily distinguished from them by the size and arrangement of the plates: in $Q$. quadrigera shell plates are relatively small and similar in size $(8-10 \mu \mathrm{m})$, arranged in numerous rows, often mixed with single round or elliptical plates; in Q. scutellata, small quadrangular plates are usually superimposed at the junctions of the larger plates. The analysis of the variation coefficients shows that the population of the newly described species is homogeneous and all characters and ratios measured are weakly to moderate variable ( $\mathrm{CV}$ range from $4.98 \%$ to $9.78 \%$ ). The shell length, breadth and depth, as well as length/breadth ratio are the most stable characters (CV between $4.98 \%$ and 6.79\%). Moderate variability is observed for the aperture and breadth/aperture ratio $(9.24 \%$ and $9.72 \%$, respectively). Our study of many individuals of $Q$. longicollis gives us evidence to support the view that it is a welldefined and independent species, clearly distinguishable from $Q$. symmetrica and $Q$. variabilis. We discuss the high morphological and morphometric variability of $Q$. symmetrica and the need for molecular studies of European narrow-shelled and tubular forms, very similar to the recently described South African species $Q$. madibai, to elucidate their taxonomic status. We synonymise Quadrulella symmetrica var. irregularis Penard, in Wailes and Penard, 1911 with Quadrulella longicollis (Taranek, 1882).
\end{abstract}

Key words: Amoebozoa, distribution, morphology, morphometry, taxonomy, testate amoebae

doi:10.21685/1680-0826-2021-15-2-1 


\section{Introduction}

Hyalospheniid testate amoebae (Amoebozoa: Arcellinida: Hyalospheniidae) include comparatively large and widespread species, inhabiting mainly Sphagnum peatlands, freshwater pools, wet mosses and forest litter. They form a significant part of the microbial ecosystem in peatland soils and are considered as important bioindicators, increasingly used in environmental monitoring and palaeoecology (Charman, 2001; Booth, 2002; Mitchell et al., 2008a, 2008b; Meyer et al., 2012; Payne et al., 2012, 2021; Lamentowicz et al., 2013; Paterson et al., 2013; Turner et al., 2013; Marcisz et al., 2015, 2020; Swindles et al., 2015; Amesbury et al., 2016, 2018). They also play a central role in the food webs in peatlands, enhancing nutrient cycles by consuming bacteria, protozoa, microalgae, fungi and micrometazoa (Gilbert et al., 1998; Lamentowicz and Mitchell, 2005; Mitchell et al., 2008a; Jassey et al., 2015).

The genus Quadrulella is one of the most characteristic hyalospheniid genera, which differs from the other genera of this family by self-secreted quadrangular siliceous plates used in the building of the shell. The genus includes about twenty small to medium-sized (about 70-150 $\mu \mathrm{m})$ species and subspecies, most of which are very rare and distributed only in Africa and South America. Quadrulella symmetrica (Wallich, 1864) Cockerell, 1909 is a type species of the genus with a cosmopolitan distribution. Most of the findings of Quadrulella specimens in Europe and in Holarctic in general have been assigned to this species or to its infrasubspecific taxa. Until recently, $Q$. symmetrica was thought to be a single species, but recent studies of Kosakyan et al. (2012, 2016) revealed an unexpected morphological and genetic variability of this taxon and showed that this is a species complex with at least four different species. Kosakyan et al. (2016) demonstrate that morphological traits such as shell size and shape, size and arrangement of quadrangular shell-plates are efficient criteria for species discrimination. Based on morphology and sequence data they described two new species ( $Q$. variabilis and $Q$. madibai) and transfer two of the previously described Quadrulella species ( $Q$. subcarinata and Q. plicata) into a new genus Mrabella, which distinctive features are the presence of a pronounced lateral hollow keel, as well as the different origin of the shell-plates, which are probably not self-secreted, so it is assumed that it is kleptosquamy (Kosakyan et al., 2016). It is interesting to note that another Quadrulella species (Q. texcalense) has been described recently from an unexpected arid environment - extremely dry soil from the intertropical desert in Mexico (PérezJuárez et al., 2017). The fact that new species of the relatively well studied genus Quadrulella still being discovered and described confirms that the diversity in hyalospheniid testate amoebae, as in many other microbial eukaryotes, has been underestimated. Therefore, more intensive molecular and morphological studies based on a large number of populations are needed to clarify the true diversity of the genus Quadrulella, as well as of hyalospheniid testate amoebae in general.

The aims of the present study were: (1) to provide distributional data, morphological and morphometric descriptions of all Quadrulella species recorded from Bulgaria so far; (2) to describe Quadrulella deflandrei sp. nov.

\section{Material and methods}

The data for the distribution of the Quadrulella species in Bulgaria are based primarily on data existing in the literature and additional data from our research conducted over the past five years. The material for the morphological and morphometric characterization of the species was extracted from wet Sphagnum mosses, gathered at Vitosha Mts., Stara Planina Mts., Rila Mts., Pirin Mts. and Rhodopes Mts. in the period during 2016-2020. A map with the known localities of Quadrulella species in Bulgaria is presented in Fig. 1.

Testate amoebae were extracted from fresh Sphagnum mosses at the sampling site and concentrated by sieving $(350 \mu \mathrm{m})$. The resulting fraction (50 ml) was observed with optical microscope "Amplival" (Zeiss-Jena) using $40 \times$ objective and $10 \times$ oculars lens. For scanning electron microscopy (SEM), specimens were isolated by searching through small isolates of material in a petri dish. Specimens were extracted using a glass micropipette, washed several times in distilled water, and then individual shells were positioned with a singlehair brush on a previously mounted double-sided adhesive tape on a standard aluminium stub and air-dried. The shells were coated evenly with gold in a vacuum coating unit. The photomicrographs were obtained using a JEOL JSM-5510, operating at $10 \mathrm{kV}$. 


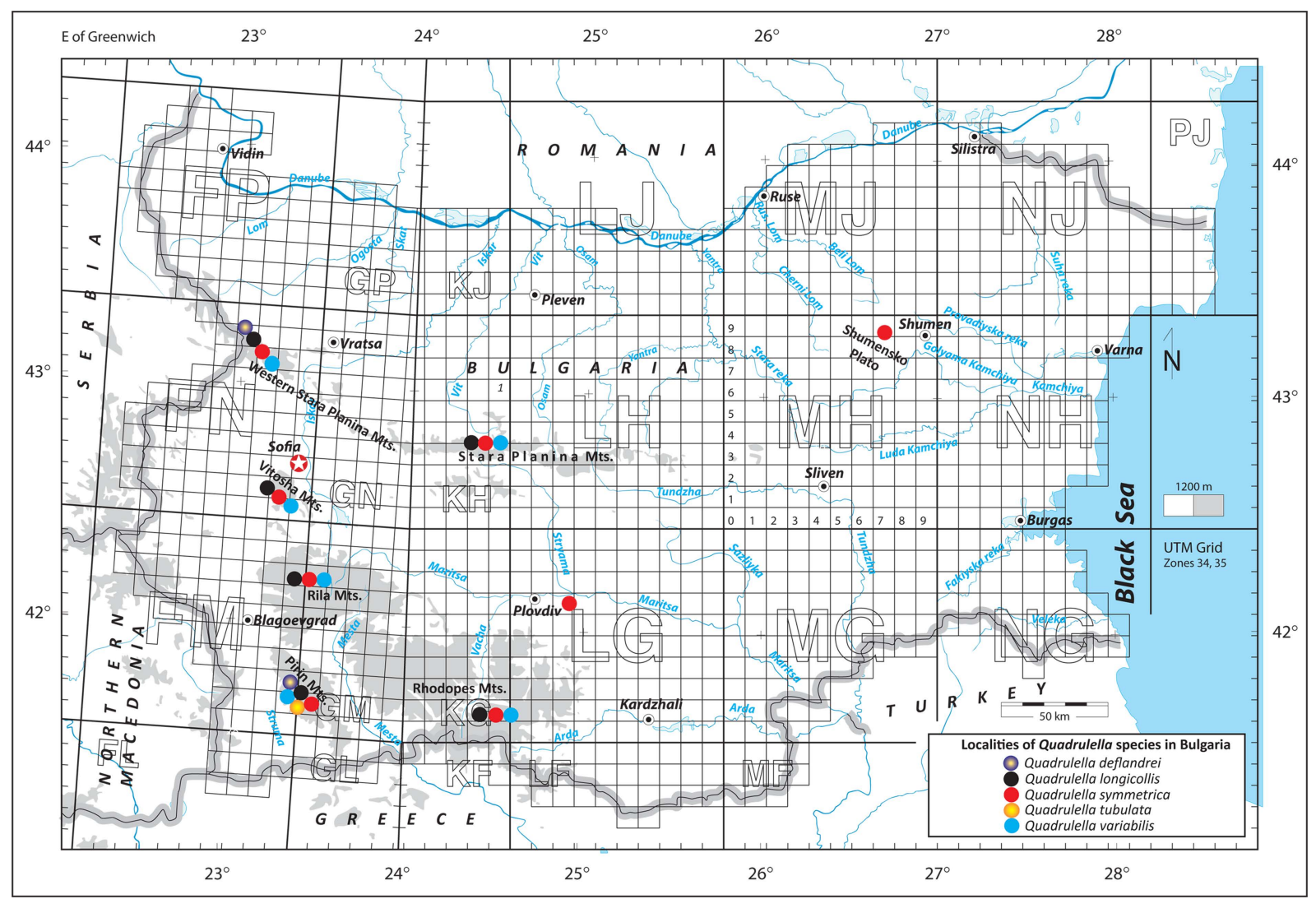

Fig. 1. Localities of Quadrulella species in Bulgaria.

The morphometric data are based on original and new measurements performed in 2020 within the project under the National Research Programme "Young scientists and postdoctoral students". For morphometric characterization of the species, the following characters and ratios were measured: length, breadth, depth, aperture, length/breadth and breadth/aperture. The following basic statistics were calculated: arithmetic mean; median (M); standard deviation (SD); standard error of mean (SE); coefficient of variation in \% (CV); extreme values (Min and Max). Frequency distribution analysis was carried out in order to describe variation of characters. Statistical analysis was performed using the computer program STATISTICA, version 7.0.

\section{Results}

A total of five species of Quadrulella have been found in Bulgaria so far. One of them (Quadrulella tubulata) has been recorded only once from Popovo Lake in Pirin Mts. (Golemansky, 1974), and has not been found in our study. We found four species, one of which is new and is described below. For the morphometric characterization of the found Quadrulella species, the basic morphometric characters of 700 individuals were measured and the results are given in Table 1.

QUADRULELLA DEFLANDREISP. NOV.

(Figs 2; 3, A; Table 1)

Description: Shell large, colourless, ovoid or pyriform in broad view, with sides tapering evenly and gradually from rounded aboral region towards aperture; laterally compressed, with oval transverse section; composed of quadrangular siliceous shell plates of very different sizes, usually mixed and arranged in irregular rows, rarely regularly arranged; aperture oval, slightly convex frontally and concave laterally, bordered by a thin collar of organic cement (Fig. 2). Dimensions (based on 22 individuals): $\mathrm{L}=$ $136-167 \mu \mathrm{m}, \mathrm{B}=85-102 \mu \mathrm{m}, \mathrm{D}=39-45 \mu \mathrm{m}, \mathrm{A}=$ $33-47 \mu \mathrm{m}$.

Differential diagnosis: Quadrulella deflandrei resembles $Q$. symmetrica in its general shape but differs from it by about twice larger size $(\mathrm{L}=150.8$ $\pm 7.51, \mathrm{~B}=93.5 \pm 4.91, \mathrm{D}=41.9 \pm 2.30, \mathrm{~A}=38.1$ \pm 3.52 in $Q$. deflandrei vs. $\mathrm{L}=83.5 \pm 4.55, \mathrm{~B}=$ 
Table 1. Morphometric characterization of Quadrulella species from Bulgaria: $M$ - median; SD - standard deviation; SE - standard error of the mean; CV - coefficient of variation in \%; Min - minimum; Max - maximum; $n$ - number of individuals examined (measurements in $\mu \mathrm{m}$ ).

\begin{tabular}{|c|c|c|c|c|c|c|c|c|}
\hline Characters & Mean & M & SD & SE & CV & Min & Max & $\mathbf{n}$ \\
\hline \multicolumn{9}{|c|}{ Quadrulella deflandrei sp. nov. } \\
\hline Length (L) & 150.8 & 150.0 & 7.51 & 1.60 & 4.98 & 136 & 167 & 22 \\
\hline Breadth (B) & 93.5 & 94.0 & 4.91 & 1.05 & 5.24 & 85 & 102 & 22 \\
\hline Aperture (A) & 38.1 & 37.0 & 3.52 & 0.75 & 9.23 & 33 & 47 & 22 \\
\hline Depth (D) & 41.9 & 42.5 & 2.30 & 0.81 & 5.48 & 39 & 45 & 8 \\
\hline Length/Breadth ratio (L/B) & 1.62 & 1.62 & 0.11 & 0.02 & 6.64 & 1.40 & 1.82 & 22 \\
\hline Breadth/Aperture ratio $(\mathrm{B} / \mathrm{A})$ & 2.47 & 2.47 & 0.24 & 0.05 & 9.70 & 1.87 & 2.85 & 22 \\
\hline \multicolumn{9}{|c|}{ Quadrulella longicollis } \\
\hline Length (L) & 119.3 & 119.0 & 6.57 & 0.51 & 5.51 & 103 & 137 & 164 \\
\hline Breadth (B) & 54.1 & 54.1 & 4.02 & 0.31 & 7.43 & 42 & 62 & 164 \\
\hline Aperture (A) & 22.3 & 22.0 & 2.15 & 0.17 & 9.64 & 17 & 30 & 164 \\
\hline Depth (D) & 38.8 & 38.0 & 3.53 & 0.34 & 9.09 & 32 & 50 & 108 \\
\hline Length/Breadth ratio (L/B) & 2.21 & 2.20 & 0.15 & 0.01 & 6.97 & 1.84 & 2.71 & 164 \\
\hline Breadth/Aperture ratio $(\mathrm{B} / \mathrm{A})$ & 2.44 & 2.44 & 0.22 & 0.02 & 9.20 & 1.54 & 3.06 & 164 \\
\hline \multicolumn{9}{|c|}{ Quadrulella symmetrica } \\
\hline Length (L) & 85.3 & 85.0 & 4.55 & 0.23 & 5.34 & 72 & 99 & 394 \\
\hline Breadth (B) & 47.7 & 47.0 & 3.59 & 0.18 & 7.52 & 40 & 61 & 394 \\
\hline Aperture $(A)$ & 20.3 & 20.0 & 1.67 & 0.08 & 8.24 & 16 & 26 & 394 \\
\hline Depth (D) & 31.7 & 32.0 & 2.43 & 0.20 & 7.66 & 22 & 43 & 143 \\
\hline Length/Breadth ratio (L/B) & 1.80 & 1.79 & 0.13 & 0.006 & 7.01 & 1.50 & 2.28 & 394 \\
\hline Breadth/Aperture ratio $(\mathrm{B} / \mathrm{A})$ & 2.36 & 2.35 & 0.19 & 0.01 & 8.14 & 1.82 & 3.12 & 394 \\
\hline \multicolumn{9}{|c|}{ Quadrulella variabilis } \\
\hline Length (L) & 71.6 & 71.2 & 2.67 & 0.24 & 3.74 & 66 & 80 & 120 \\
\hline Breadth (B) & 37.1 & 37.0 & 2.42 & 0.22 & 6.52 & 32 & 45 & 120 \\
\hline Aperture (A) & 16.5 & 16.0 & 1.72 & 0.16 & 10.46 & 13 & 23 & 120 \\
\hline Depth (D) & 25.7 & 26.0 & 3.11 & 0.48 & 12.12 & 21 & 31 & 42 \\
\hline Length/Breadth ratio (L/B) & 1.94 & 1.94 & 0.12 & 0.01 & 6.39 & 1.60 & 2.43 & 120 \\
\hline Breadth/Aperture ratio $(\mathrm{B} / \mathrm{A})$ & 2.26 & 2.25 & 0.18 & 0.02 & 8.09 & 1.38 & 2.64 & 120 \\
\hline \multicolumn{9}{|c|}{ Quadrulella tubulata (after Gauthier-Lièvre, 1953) } \\
\hline Length (L) & - & - & - & - & - & 70 & 100 & - \\
\hline Breadth (B) & - & - & - & - & - & 42 & 50 & - \\
\hline Aperture (A) & - & - & - & - & - & 20 & 22 & - \\
\hline Depth (D) & - & - & - & - & - & 30 & 30 & - \\
\hline Length of neck (Ln) & - & - & - & - & - & 30 & 45 & - \\
\hline
\end{tabular}

$47.7 \pm 3.59, \mathrm{D}=31.7 \pm 2.43, \mathrm{~A}=20.3 \pm 1.67$ in $Q$. symmetrica). Furthermore, $Q$. deflandrei has significantly more and larger shell plates (maximum size 15-19 $\mu \mathrm{m})$, arranged in 14-17 transverse and 9-11 longitudinal rows (Fig. 3, A) vs. a maximum plate size of $10-12 \mu \mathrm{m}$ in $Q$. symmetrica, arranged in 9-12 transverse and 5-7 longitudinal rows (Fig. $3, \mathrm{C})$. On the other hand, Q. deflandrei has a similar size as $Q$. quadrigera and $Q$. squtellata but can be easily distinguished from them by the size and arrangement of the plates: in $Q$. quadrigera, shell plates are relatively small and similar in size $(8-10$ 

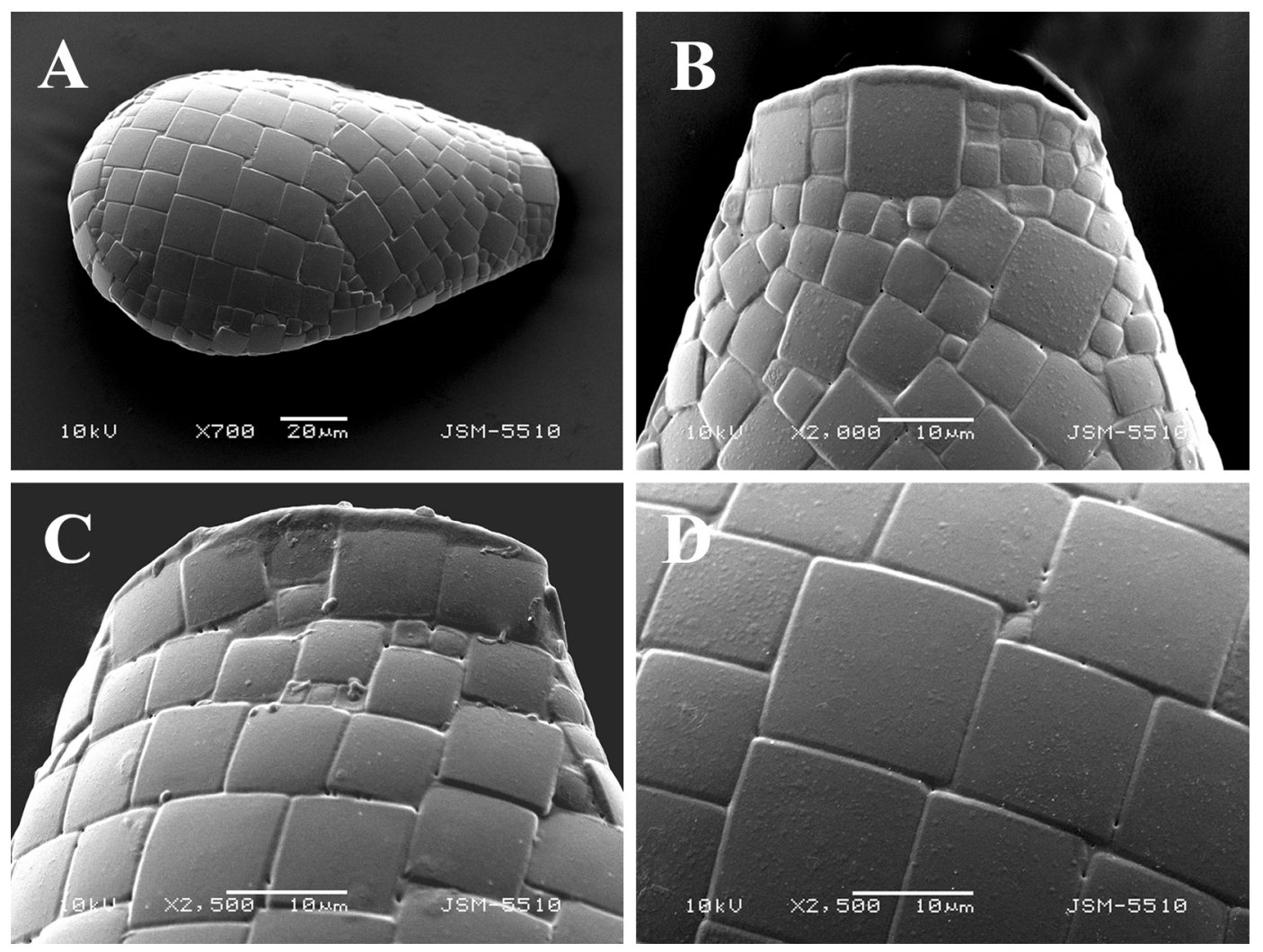

Fig. 2. SEM micrographs of Quadrulella deflandrei sp. nov. A - Broad lateral view showing the general shape of the shell; B, C - broad lateral view of apertural region of two individuals showing quadrangular shell plates with very different size, convex frontally aperture and bordering thin collar of organic cement; D - detail of shell surface in the largest region of the shell.

$\mu \mathrm{m})$, arranged in numerous rows (18-22 transverse and 13-15 longitudinal), often mixed with single round or elliptical plates; in $Q$. scutellata, small quadrangular plates are usually superimposed at the junctions of the larger plates. Moreover, $Q . q u-$ adrigera and $Q$. squtellata are distributed mainly in North and South America, Asia and Africa, and for Europe, there is only one record for $Q$. squtellata from Hungary, which is dubious because there is no illustration (Grospietsch, 1982).

Morphometry: The morphometric characterization of $Q$. deflandrei is given in Table 1 . The analysis of the variation coefficients shows that the studied population of the newly described species is homogeneous and all characters and ratios measured are weakly to moderate variable (CV range from $4.98 \%$ to $9.78 \%$ ). The shell length, breadth and depth, as well as length/breadth ratio are the most stable characters (CV between $4.98 \%$ and $6.79 \%$ ). Moderate variability is observed for the aperture and breadth/aperture ratio $(9.24 \%$ and $9.72 \%$, respectively).
Ecology: Quadrulella deflandrei inhabits wet moss Sphagnum flexuosum Dozy and Molk., growing in a small mire in a mixed deciduous forest of beech (Fagus sylvatica L.) and birch (Betula pendula L.), at 881 m a.s.l. in the Western Stara Planina Mts. (Bulgaria). It was found in association with the dominant species Assulina muscorum, Corythion dubium, Heleopera rosea, Nebela collaris and Quadrulella symmetrica, and with some other hyalospheniids, presented with a small number of individuals, such as Longinebela tubulosa, Nebela guttata, N. pechorensis, Padaungiella lageniformis, P. tubulata, Quadrulella longicollis and $Q$. variabilis. The habitat, where almost all $Q$. deflandrei specimens were found, is characterized by an acid reaction of the environment $(\mathrm{pH}=5.05)$, low conductivity of the water $(86.4 \mu \mathrm{S})$, moderate water content of the moss $(93.5 \%)$ and low water table depth $(0 \mathrm{~cm})$. Only one of all 22 specimens was found in another area in the Pirin Mts., in Sphagnum teres (Schimp.) Engstr. near the Popovo Lake. The main physico-chemical parameters in this locality were almost the same as those 


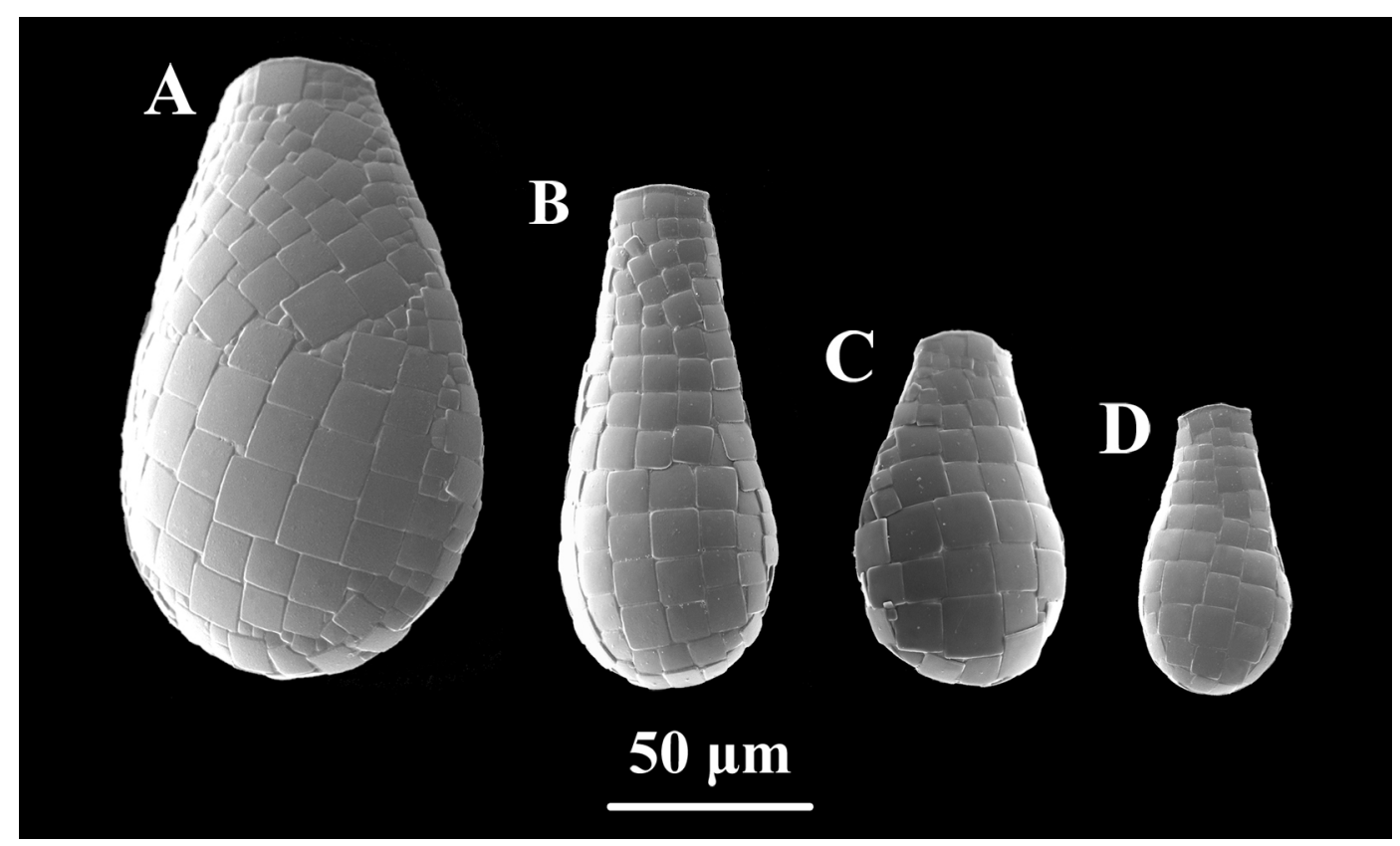

Fig. 3. SEM micrographs of four found in this study Quadrulella species from Bulgaria at the same magnification. A - Quadrulella deflandrei; B - Quadrulella longicollis; C - Quadrulella symmetrica; D - Quadrulella variabilis.

in the previous one: acid reaction of the environment $(\mathrm{pH}=5.51)$, low conductivity of the water $(51.5 \mu \mathrm{S})$, high water content of the moss $(95.7 \%)$ and low water table depth $(0 \mathrm{~cm})$.

Type locality: The surroundings of the Village Kopilovtsi below the hut "Kopren", Western Stara Planina Mountain, Bulgaria (43.33044 N, 22.86055 E, $881 \mathrm{~m}$ a.s.1.).

Type specimen: Holotype and paratypes mounted in Canada balsam on a glass slide are retained in the collection of Dr. M. Todorov, Institute of Biodiversity and Ecosystem Research, BAS, Sofia; preparations №№ QD-H/2021 (holotype) and QD-P01/2021, QD-P-02/2021 (paratypes).

Material from type locality: Retained by the authors in sample № 225/2016, collected on November 22, 2016.

Etymology: This species is named after Dr. Georges Deflandre, a prominent French scientist in the field of micropaleontology and protistology, who first illustrated an unusual large form of Quadrulella symmetrica, very similar to the individuals we found.

Geographical distribution: Europe: Bulgaria, France.

Distribution in Bulgaria: Sphagnum mosses in Stara Planina Mts. and Pirin Mts.

Remarks: No living specimens were observed and the description is based on 22 empty shells.
QUADRULELLA LONGICOLLIS (TARANEK, 1882)

(Figs 3, B; 4; Table 1)

Quadrulella symmetrica var. longicollis Taranek, 1882 - Abh. König. Böhm. Ges. der Wiss., 11, p. 48, Taf. IV, fig. 19.

Quadrulella symmetrica var. irregularis Penard, in Wailes and Penard, 1911 - Proc. R. Irish Acad., 31 (3), p. 51-52, Pl. VI, fig. 31.

Quadrulella longicollis (Taranek, 1882) - Kosakyan et al., 2012, Protist, 163, p. 429, fig. 5 D.

Description: Shell colourless, transparent, elongate-pyriform, with a distinct long neck and sides tapering evenly and gradually from rounded aboral region towards aperture; laterally compressed, with oval transverse section; composed of quadrangular shell-plates with different size, smaller near the aperture, arranged in horizontal or helical rows; aperture terminal, oval, slightly convex frontally and concave laterally, bordered by a thin collar of organic cement (Figs 3, B; 4). Dimensions (based on 164 individuals): $\mathrm{L}=103-137 \mu \mathrm{m}, \mathrm{B}=42-62$ $\mu \mathrm{m}, \mathrm{D}=32-50 \mu \mathrm{m}, \mathrm{A}=17-30 \mu \mathrm{m}$.

Notes: Quadrulella longicollis differs: (1) from $Q$. symmetrica by its larger size $(\mathrm{L}=119.3 \pm 6.57$ in $Q$. longicollis vs. $85.3 \pm 4.55$ in $Q$. symmetrica) and by the elongated shell with pronounced long neck 


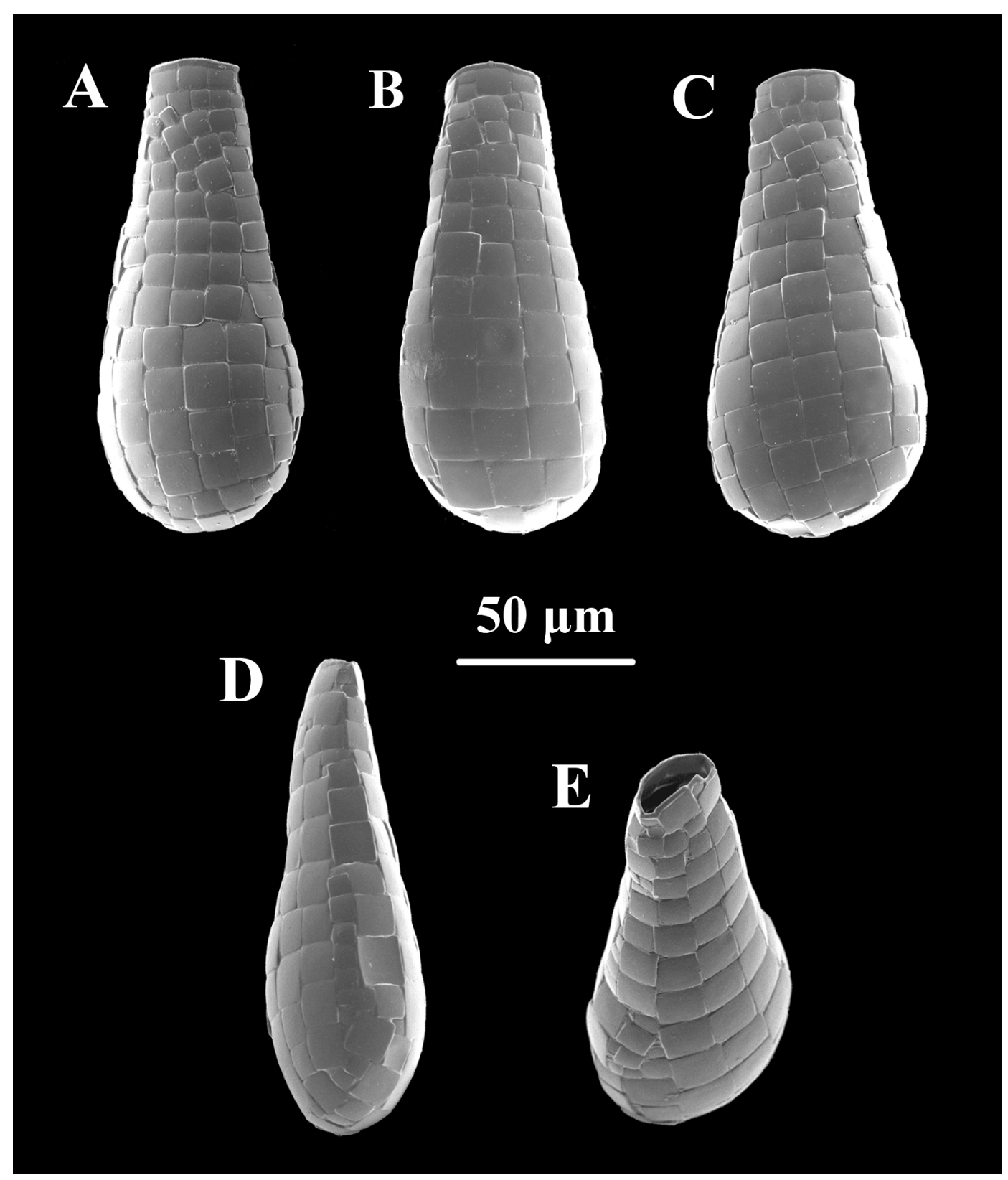

Fig. 4. SEM micrographs of Quadrulella longicollis. A-C - Broad lateral view of three individuals to illustrate variability in shape and shell structure, and convex frontally aperture; D - narrow lateral view showing shell compression; E - latero-apertural view showing elliptical shape of the aperture and bordering thin collar of organic cement.

$(\mathrm{L} / \mathrm{B}=2.21 \pm 0.15$ in $Q$. longicollis vs. $1.80 \pm 0.13$ in $Q$. symmetrica); (2) from $Q$. variabilis mainly by its larger size $(\mathrm{L}=119.3 \pm 6.57, \mathrm{~B}=54.1 \pm 4.02 \mathrm{in}$ Q. longicollis vs. $\mathrm{L}=71.6 \pm 2.67, \mathrm{~B}=37.1 \pm 2.42$ in $Q$. variabilis).

Morphometry: see Table 1.

Ecology: Common in Sphagnum and wet soil mosses.

Geographical distribution: Cosmopolitan.
Distribution in Bulgaria: (recorded as Quadrulella longicollis) Pirin, Rhodopes, Rila, Stara Planina and Vitosha Mts. (Bankov et al., 2018; Todorov and Bankov, 2019); (recorded as Q. symmetrica var. longicollis) Rhodopes Mts. (Golemansky, 1967, 1968; Golemansky et al., 2006; Todorov et al., 2008); Rila Mts. (Golemansky and Todorov, 1993; Todorov and Golemansky, 2000; Todorov, 2004, 2005); Vitosha Mts. (Golemansky, 1965; 


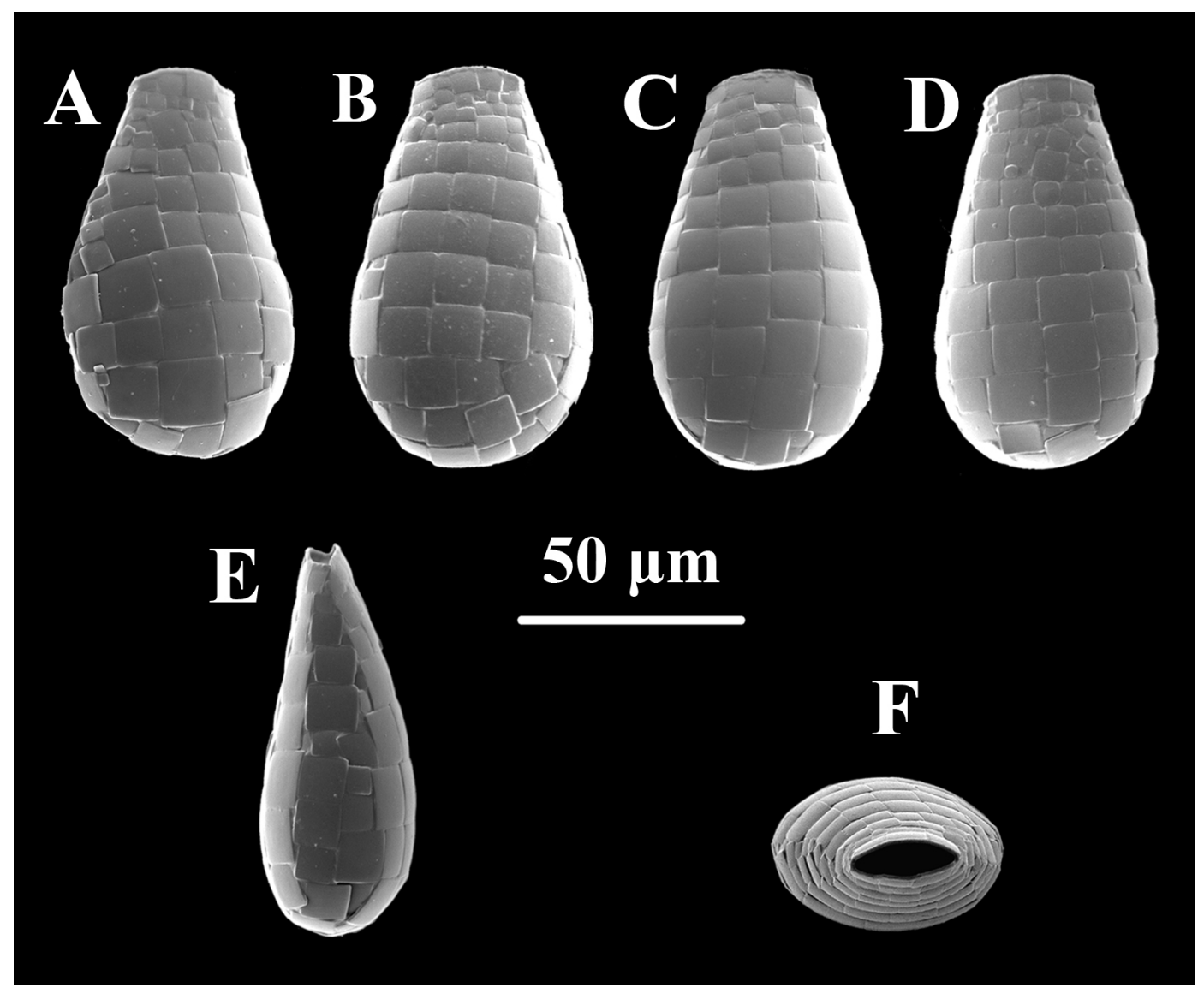

Fig. 5. SEM micrographs of Quadrulella symmetrica. A-D - Broad lateral view of four individuals to illustrate variability in shape and shell structure, and convex frontally aperture; E - narrow lateral view showing shell compression and concave laterally aperture; F - apertural view showing elliptical shape of the aperture.

Golemansky and Todorov, 1985, 1990; Todorov, 1993; Todorov and Golemansky, 1995); (recorded as Quadrulella symmetrica var. irregularis) Pirin Mts. (Golemansky, 1974); Rhodopes Mts. (Golemansky, 1967, 1968); Rila Mts. (Golemansky and Todorov, 1993; Vitosha Mts. (Golemansky, 1965; Golemansky and Todorov, 1985; Todorov, 1993; Todorov and Golemansky, 1995).

Quadrulella Symmetrica (WAllich, 1863), CockeRELL, 1909

(Figs 3, C; 5; Table 1)

Difflugia proteiformis var. symmetrica Wallich, 1863 - Ann. Mag. Nat. Hist., v. 12, no 72, p. 458, Pl. 8, fig. 16;

Quadrulella symmetrica (Wallich, 1864) Cockerell, 1909 - Zoologischer Anzriger, 34: 565.

Description: Shell colourless, transparent, ovoid or pyriform, with sides tapering evenly and gradually from rounded aboral region towards aperture; laterally compressed, with oval transverse section; composed of quadrangular shell-plates, usually arranged in rows, smaller near the aperture and gradually getting larger towards rounded aboral area; aperture terminal, oval, slightly convex frontally and concave laterally, bordered by a thin collar of organic cement (Figs 3, C; 5). Dimensions (based on 394 individuals): $\mathrm{L}=72-99 \mu \mathrm{m}, \mathrm{B}=40-61 \mu \mathrm{m}$, $\mathrm{D}=22-43 \mu \mathrm{m}, \mathrm{A}=16-26 \mu \mathrm{m}$.

Notes: Quadrulella symmetrica differs: (1) from $Q$. longicollis by its smaller size $(\mathrm{L}=85.3 \pm 4.55$ in $Q$. symmetrica vs. $119.3 \pm 6.57$ in $Q$. longicollis) and by its more ovoid to pyriform shell without pronounced long neck $(\mathrm{L} / \mathrm{B}=1.80 \pm 0.13$ in $Q$. symmetrica vs. $2.21 \pm 0.15$ in $Q$. longicollis); (2) from $Q$. variabilis mainly by its larger size of the shell and shell-plates $(\mathrm{L}=85.3 \pm 4.55$ and maximum shell-plate size $10-12 \mu \mathrm{m}$ in $Q$. symmetrica vs. $71.6 \pm 2.67$ and $7-9$ $\mu \mathrm{m}$ in $Q$. variabilis).

Morphometry: see Table 1.

Ecology: Common in Sphagnum, less frequent in 


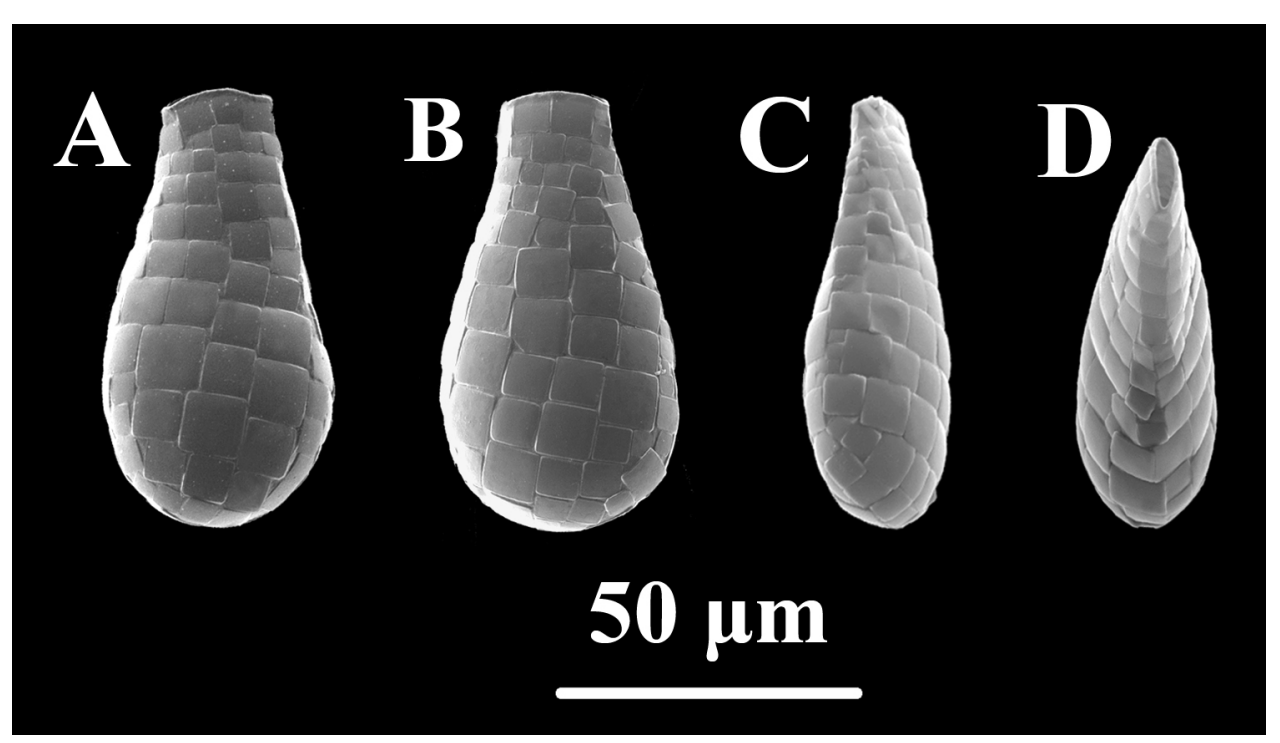

Fig. 6. SEM micrographs of Quadrulella variabilis. A, B - Broad lateral view of two individuals showing general shape and thin collar of organic cement bordering aperture; $\mathrm{C}$ - narrow lateral view showing shell compression. (D) latero-apertural view showing narrow elliptical shape of the aperture.

littoral zone of lakes and in hydrophilic soil mosses.

Geographical distribution: Cosmopolitan.

Distribution in Bulgaria: (recorded as Quadrulella symmetrica) Pirin Mts. (Valkanov, 1932; Golemansky, 1974; Bankov et al., 2018; Todorov and Bankov, 2019); Rhodopes Mts. (Pateff, 1924; Golemansky, 1967, 1968; Golemansky et al., 2006; Bankov et al., 2018; Todorov and Bankov, 2019); Rila Mts. (Pateff, 1924; Valkanov, 1932; Golemansky and Todorov, 1993; Todorov, 1993, 2004, 2005; Todorov and Golemansky, 2000; Bankov et al., 2018; Todorov and Bankov, 2019); Shumensko Plato (Davidova, 2003); Stara planina Mts. (Bankov et al., 2018; Todorov and Bankov, 2019); Swamps near Plovdiv (Pateff, 1924; Golemansky, 1966); Vitosha Mts. (Pateff, 1924; Golemansky, 1965; Golemansky and Todorov, 1985, 1990; Todorov, 1993; Todorov and Golemansky, 1995; Kosakyan et al., 2012; Bankov et al., 2018; Todorov and Bankov, 2019).

Quadrulella Variabilis Kosakyan, Lahr, Mulot, Meisterfeld, Mitchell and LaRa, 2016 (Figs 3 D, 6; Table 1)

Quadrulella variabilis Kosakyan et al. 2016, Cladistics, 32, p. 15, fig. 2.

Description: Shell colourless, transparent, ovoid or pyriform, with sides tapering gradually from rounded aboral region towards aperture, sometimes forming elongated neck; laterally compressed, with oval to ellipsoidal transverse section; composed of quadrangular shell-plates with different size, smaller near the aperture, usually arranged in rows; aperture terminal, oval, slightly convex frontally and concave laterally, bordered by a thin collar of organic cement (Figs 3, D; 6). Dimensions (based on 120 individuals): $\mathrm{L}=66-80 \mu \mathrm{m}, \mathrm{B}=32-45 \mu \mathrm{m}$, $\mathrm{D}=21-31 \mu \mathrm{m}, \mathrm{A}=13-23 \mu \mathrm{m}$.

Notes: Quadrulella variabilis differs: (1) from $Q$. symmetrica with smaller size of the shell and shell-plates $(\mathrm{L}=71.6 \pm 2.67$ and maximum shellplate size $7-9 \mu \mathrm{m}$ in $Q$. variabilis vs. $85.3 \pm 4.55$ and $10-12 \mu \mathrm{m}$ in $Q$. symmetrica); (2) from $Q$. longicollis by its smaller shell $(\mathrm{L}=71.6 \pm 2.67$ in $Q$. variabilis vs. $119.3 \pm 6.57$ in $Q$. longicollis) and not so well defined long neck.

Morphometry: see Table 1.

Ecology: Sphagnum mosses.

Geographical distribution: Recently described from Switzerland, still unknown.

Distribution in Bulgaria: Sphagnum mosses in Pirin, Rhodopes, Rila, Stara Planina and Vitosha Mts. (Bankov et al., 2018; Todorov and Bankov, 2019).

Quadrulella tubulata (GAUTHIER-LièVRe, 1953)

(Fig. 7; Table 1)

Quadrulella symmetrica var. tubulata GauthierLièvre, 1953 - Bull. Soc. Hist. Nat. de l'Afrique du Nord, 44 (7/8): p. 330, fig. 2 D, E). 


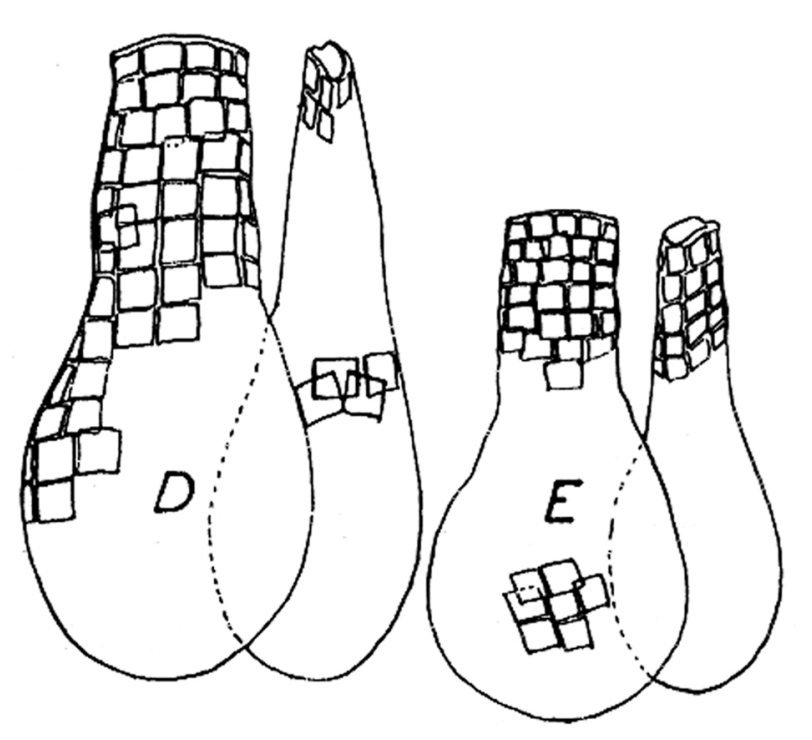

Fig. 7. Quadrulella tubulata. Original drawings after Gauthier-Lièvre (1953): typical forms from Congo (D) and from Ivory Coast (E).

Quadrulella tubulata (Gauthier-Lièvre, 1953) Gauthier-Lièvre et Thomas, 1961. Bull. Soc. Hist. Nat. de l'Afrique du Nord, 52: p. 44.

Description (based on the original description): Shell colourless, transparent, flask-shaped or bottle shaped in broad view, with a distinct slender and elongated neck with parallel sides, and a rounded aboral region; laterally compressed, especially in the apertural region, with oval transverse section; composed of quadrangular or rectangular shellplates, arranged in rows or irregularly; aperture terminal, oval, straight or slightly convex frontally and concave laterally, bordered or not by a thin collar of organic cement (Fig. 7). Dimensions (after Gauthier-Lièvre, 1953): $\mathrm{L}=70-100 \mu \mathrm{m}, \mathrm{B}=42-50$ $\mu \mathrm{m}, \mathrm{D}=30 \mu \mathrm{m}, \mathrm{Ln}=30-45 \mu \mathrm{m}, \mathrm{A}=20-22 \mu \mathrm{m}$.

Notes: Quadrulella tubulata differs: (1) from $Q$. longicollis by its smaller shell size and distinct slender neck with parallel sides; (2) from elongated forms of $Q$. varabilis by its distinct neck, which in $Q$. varabilis has sides tapering gradually towards the aperture.

Ecology: Aquatic, wet mosses; rare species.

Geographical distribution: Africa: Congo (Gauthier-Lièvre, 1953, 1957), Ivory Coast (GauthierLièvre, 1953), Gabon (Gauthier-Lièvre, 1957), Cameroon (Gauthier-Lièvre, 1957), Guinea (Declootre, 1955; Golemansky, 1962); Europe: Bulgaria (Golemansky, 1974), Romania (Godeanu, 1981), Spain (Gracia, 1972); South America: Argentina (Vucetich, 1983; Vucetich and Lopretto, 1995), Brazil (Walker, 1982); Australia: New Guinea (Gracia, 1968).
Distribution in Bulgaria: Popovo Lake in Pirin Mts. (Golemansky, 1974).

\section{Discussion}

In testate amoebae, as in many microbial eukaryotes, high variability of the main morphological and morphometric characters is common in different individuals of a given species, especially when comparing populations from different habitats and geographical regions (Bobrov and Mazei, 2004). This polymorphism of some species has led to the description of many taxa based on small differences in shell size and shape, and to oversplitting of the group. This is the reason for the presence in the literature of many poorly described species and infrasubspecific taxa (varieties and forms), the validity of which is doubtful. Therefore, we support a more conservative approach when it comes to splitting morphologically related species and the view that if the separation is only based on morphometric features, then the distances between the main characters of the species should be very distinct (around and over 100\%), and there should be no intermediate forms between them (Foissner and Korganova, 1995; Tsyganov and Mazei, 2006). Of course, it would be better if one or more reliable morphological characters or molecular studies were used together with the morphometric characters to separate the species.

In our study of the genus Quadrulella from Bulgaria we found some individuals that in their general shape resemble $Q$. symmetrica but clearly differ from it by about twice larger size and high variability in the size and arrangement of the shell plates. Furthermore, in the same habitat where we found those large individuals, $Q$. symmetrica was also represented by many individuals that all ranged between $72 \mu \mathrm{m}$ and $99 \mu \mathrm{m}$. Besides, we did not find intermediate forms between these two species. Thus, we had enough reasons to describe the new species $Q$. deflandrei. The above-mentioned differences between $Q$. deflandrei and $Q$. symmetrica are also confirmed by the scatterplot of the shell length versus shell breadth (Fig. 8). This figure illustrates that $Q$. deflandrei can clearly be distinguished from $Q$. symmetrica, as well as from $Q$. longicollis and $Q$. variabilis, two other common species in Bulgaria.

Our individuals in their general shape, size and arrangement of the shell plates are very similar to the one illustrated by Deflandre (1936) in his monograph on the genus Quadrulella (Pl. XI, Figs $1,2)$. Deflandre found this unusual large form in 


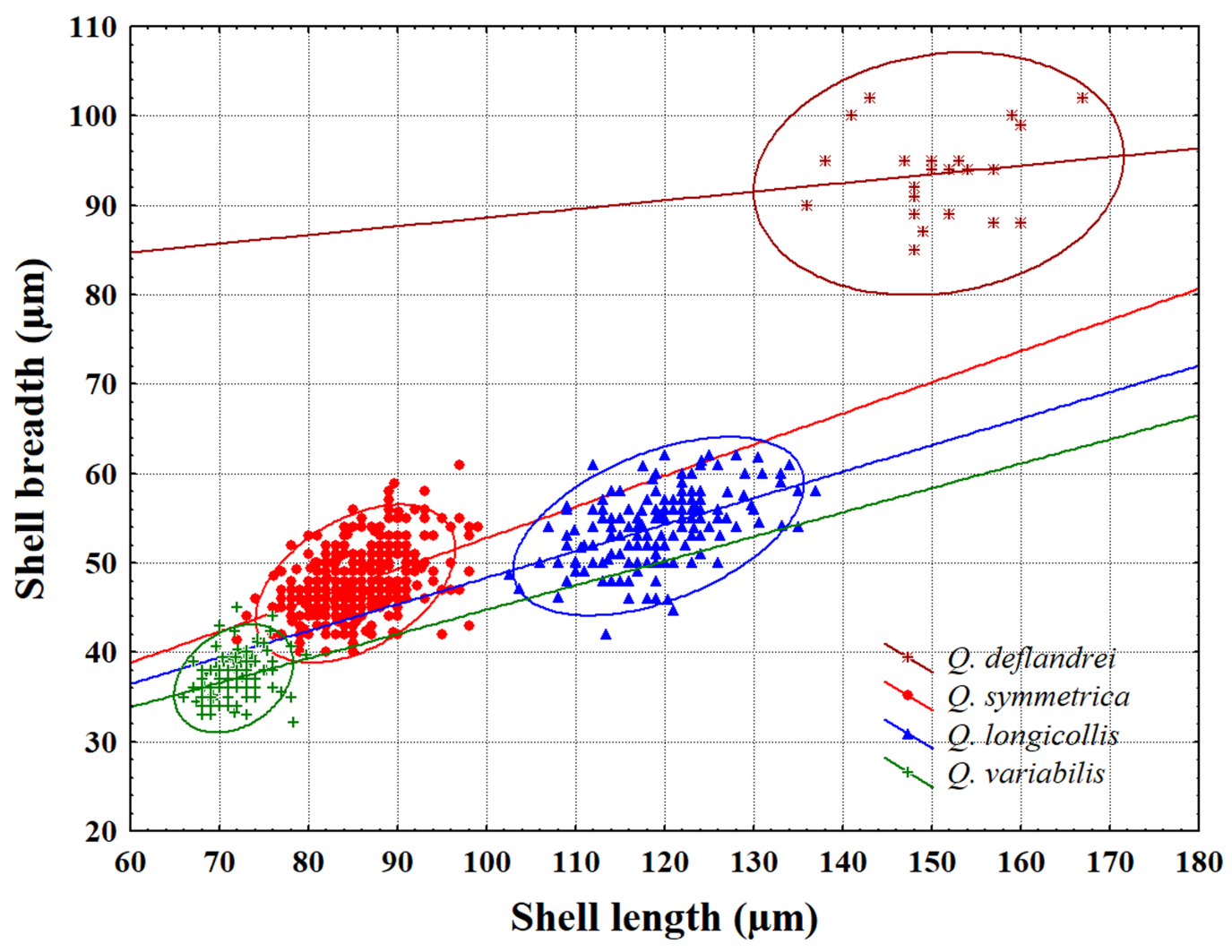

Fig. 8. Scatter plot of shell length versus shell breadth for Quadrulella species from Bulgaria found in this study (with $95 \%$ confidence ellipses).

Haute-Savoye, France and mentioned it as an intermediate form between $Q$. symmetrica var. longicollis and $Q$. symmetrica var. irregularis, without providing any name suggestion.

The presence of a large form of $Q$. symmetrica was also noted by Chardez (1967) in the 'Monographie du genre Quadrulella', where he gave illustrations and quite brief information for the forms 'minor' and 'major': ' $f$. minor réunit toutes les symmetrica typique dont la longueur est infürieure à $60 \mu \mathrm{m}$, and f. major réunit toutes les symmetrica typique dont la longueur est supérieure à $125 \mu \mathrm{m}$ '. Chardez cited Hoogenraad and de Groot (1940) as the authors of these two forms and indicated that they had been cited by Conrad from Belgium (Ardenne). The review of the only two works of Hoogenraad and De Groot, published in 1940 (Hoogenraad and De Groot, 1940a, 1940b), showed that they contained only information on $Q$. symmetrica, but nothing on two forms, 'minor' and 'major'. Conrad was not a specialist on rhizopods and in his publications in 1942 (Conrad, 1942a, 1942b) he pointed out that testate amoebae were determined by Hoogenraad and De Groot. In his first paper 'Sur la Faune et la
Flore d'un ruisseau de L'Ardenne belge' (Conrad, 1942a) he mentioned only $Q$. symmetrica. In the second paper 'Flagellates, Algues et Thécamébiens d'Ardenne' (Conrad, 1942b), two forms were cited: $Q$. symmetrica f. minor Hoogenraad and De Groot and $Q$. symmetrica f. major Hoogenraad and De Groot, and as a source of the information 'Zoetwaterrhizopoden en heliozoën. Fauna van Nederland, Afl. IX' (Hoogenraad and De Groot 1940) was indicated. However, as we noted above, this paper contained only information on $Q$. symmetrica. This discrepancy perhaps can be explained by the fact that Hoogenraad and De Groot helped Conrad in determination of testate amoebae and they exchanged the information, perhaps through letters, as travelling was hardly possible during the World War II. Perhaps Hoogenraad and De Groot gave Conrad a hint that there were two different forms of $Q$. symmetrica in his samples, 'minor' and 'major', and Conrad just took it for granted. However, these are just assumptions; meanwhile, what it really was? Due to the ambiguity with the taxonomic status of both forms, 'major' and 'minor', of $Q$. symmetrica, the lack of evidence of their real 
publication, as well as the great similarity of our specimens and the ones illustrated by Deflandre, we decided to name the newly described species after this prominent French scientist.

One of the recorded taxa from Bulgaria, namely $Q$. longicollis, still has unclear and debatable taxonomic status. Recently, Kosakyan et al. (2012) based on differences in test shape and up to $11 \%$ sequence divergence from other studied $Q$. symmetrica-like morphotypes concluded that $Q$. symmetrica var. longicollis is a separate species, and suggested it as independent taxon Quadrulella longicollis (Taranek, 1882). Later Kosakyan et al. (2016) based on traits, such as aperture and shell plate size, confirmed the placement of this long-necked species within $Q$. variabilis, and defined the taxonomic status of $Q$. longicollis as questionable. Luketa (2017) carried out a detailed morphological and morphometric study of $Q$. symmetrica and $Q$. longicollis from the central part of the Balkan Peninsula (East Herzegovina and Serbia). He provided morphometric characterization of Quadrulella longicollis based on 130 specimens from Šargan Mountain (Serbia) and the results of his study strongly support the opinion that this taxon is a separate species within the genus Quadrulella. Our study of numerous individuals of $Q$. longicollis also gives us solid argumentation to support the view that it is a well-defined and independent species, clearly distinguishable from $Q$. symmetrica and $Q$. variabilis. The differences between these species are well expressed as shown in Figs 3, 8 and in Table 1.

Quadrulella symmetrica var. irregularis is another taxon with unclear taxonomic status, which is named in several publications from Bulgaria. It was first mentioned by Penard (1891, p. 1073) from Rocky Mountain, USA. He gave a very brief description of this variety, without name and illustration, and pointed out as a main difference from the nominal species the large shell length $(100-150 \mu \mathrm{m})$ and great disorder in the arrangement of the shell plates. Penard (1905, p. 601) cited the name Q. symmetrica var. irregularis from Loch Ness, Scotland, but again without a precise description and illustration. For original description of $Q$. symmetrica var. irregularis, the work by Wailes and Penard (1911) is considered where its first figure is given (Pl. VI, fig. 31). Nevertheless, from the original illustration it is very difficult to distinguish this taxon from $Q$. longicollis by the general shell shape. The only difference is that in the original description it is clearly stated that var. irregularis belongs to the form (a) of $Q$. symmetrica which is lacking organic lip, whereas $Q$. longicollis has an aperture bordered by a thin collar of organic cement. However, this trait, as well as the irregular arrangement of the shell plates, is insufficient to separate these taxa considering that their size and general shape almost completely overlap. Thus, we consider Quadrulella symmetrica var. irregularis Penard, in Wailes and Penard, 1911 to be a junior synonym of Quadrulella longicollis (Taranek, 1882) and include all findings of Quadrulella symmetrica var. irregularis within the distribution range of $Q$. longicollis.

Recent DNA-based studies by Kosakyan et al. (2016) revealed an unexpected morphological and genetic variability in Quadrulella symmetrica and demonstrated that this taxon hosts at least four different genetic species, one of which is Quadrulella madibai, described from South Africa. Kosakyan et al. (2016) note that Q. madibai is morphologically similar to $Q$. symmetrica with its similar large shell plates, but can be distinguished from the latter based on its slender and elongated test (L/B ratio is $2.0-2.3$ in $Q$. madibai versus $1.7-1.9$ in $Q$. symmetrica). Moreover, the general outline of the test in $Q$. madibai is globally more tubular and does not present a distinct neck. Their molecular data clearly separate these two species (sequence divergence up to $10 \%$ ). Luketa (2015) analyzed the morphological and morphometric variability of $Q$. symmetrica population from the area of Lake Vlasina (Eastern Serbia) and based on 603 specimens he observed eight types of $Q$. symmetrica shells. Some of the illustrated specimens from the narrow-shell type (Fig. 4, C-L) are very similar to those of the described by Kosakyan et al. (2016) species $Q$. madibai. In a recent study, Luketa (2017) examined the morphological variability of $Q$. symmetrica based on two populations from the central part of the Balkan Peninsula (Šargan Mountain (Serbia), 432 specimens and Alagovac Lake region (East Herzegovina), 462 specimens). The author observed high morphological variability of $Q$. symmetrica in both studied populations, as well as the presence of narrow-shelled specimens, which are similar to Q. madibai (Figs 5, 8). Based on the detailed morphological and morphometric data presented in this study, he concluded that it is not possible to distinguish $Q$. symmetrica s.s. and $Q$. madibai, and that probably $Q$. madibai represents only one extreme line of clones.

In our study, we also found high morphological and morphometric variability of $Q$. symmetrica and observed specimens similar to $Q$. symmetrica s.s. and 
Q. madibai, as well as the presence of intermediate forms and a smooth transition between the two species. The established by us and by Luketa (2015, 2017) high morphological and morphometric variability of $Q$. symmetrica, in different populations from the Balkan Peninsula, raises the question if the found narrow-shelled specimens are European forms of the recently described species $Q$. madibai or they are extreme clones of a highly polymorphic species $Q$. symmetrica? In our opinion, due to the presence of intermediate forms, it is difficult to distinguish $Q$. symmetrica and $Q$. madibai based only on the morphology and L/B ratio. The taxonomic status of the narrow-shelled European specimens can only be established with greater certainty after molecular studies of individuals from European populations that have shape and size similar to South African individuals.

In conclusion, in this work we: 1) summarized all data on the diversity and distribution of Quadrulella species in Bulgaria; 2) described a new species Quadrulella deflandrei sp. nov.; 3) synonymized Quadrulella symmetrica var. irregularis Penard, in Wailes and Penard, 1911 with Quadrulella longicollis (Taranek, 1882); 4) discussed the high morphological and morphometric variability of $Q$. symmetrica and the need for molecular studies of European narrow-shelled and tubular forms, very similar to the recently described South African species $Q$. madibai, to elucidate reliably their taxonomic status.

\section{Acknowledgments}

This study was supported by a Bulgarian Ministry of Education and Science under the National Research Programme "Young scientists and postdoctoral students" approved by DCM \# 577/17.08.2018. We thank two anonymous reviewers for helpful and constructive comments and editorial suggestions, which enchanced the quality of the manuscript.

\section{References}

Amesbury M.J., Booth R.K., Roland T.P., Bunbury J., Clifford M.J., Charman D.J., Elliott S., Finkelstein S., Garneau M., Hughes P.D.M., Lamarre A., Loisel J., Mackay H., Magnan G., Markel E.R., Mitchell E.A.D., Payne R.J., Pelletier N., Roe H., Sullivan M.E., Swindles G.T., Talbot
J., Van Bellen S. and Warner B.G. 2018. Towards a Holarctic synthesis of peatland testate amoeba ecology: Development of a new continental-scale palaeohydrological transfer function for North America and comparison to European data. Quat. Sci. Rev. 201, 483-500. https://doi.org/10.1016/j. quascirev.2018.10.034

Amesbury M.J., Swindles G.T., Bobrov A., Charman D.J., Holden J., Lamentowicz M., Mallon G., Mazei Y., Mitchell E.A.D., Payne R.J., Roland T.P., Turner T.E. and Warner B.G. 2016. Development of a new pan-European testate amoeba transfer function for reconstructing peatland palaeohydrology. Quat. Sci. Rev. 152, 132-151. http://dx.doi.org/10.1016/j.quascirev.2016.09.024

Bankov N., Todorov M. and Ganeva A. 2018. Checklist of Sphagnum-dwelling testate amoebae in Bulgaria. Biodivers. Data J. 6. e25295. https://doi. org/10.3897/BDJ.6.e25295

Bobrov A.A. and Mazei Yu.A. 2004. Morphological variability of testate amoebae (Rhizopoda: Testacealobosea, Testaceafilosea) in natural populations. Acta Protozoologica. 43, 133-146.

Booth R.K. 2002. Testate amoebae as paleoindicators of surface-moisture changes on Michigan peatlands: modern ecology and hydrological calibration. J. Paleolimnol. 28, 329-348. https://doi. org/10.1023/A:1021675225099

Chardez D. 1967. Monographie du genre Quadrulella Cockerell (Protozoa, Rhizopoda testacea). Bull. Inst. Agron. Stat. Rech. Gembloux. 2, 230241.

Charman D.J. 2001. Biostratigraphic and palaeoenvironmental applications of testate amoebae. Quat. Sci. Rev. 20, 1753-1764. https://doi. org/10.1016/S0277-3791(01)00036-1

Cockerell T.D.A. 1909. New names for two genera of Protozoa. Zool. Anz. 34, 565.

Conrad W. 1942a. Sur la Faune et la Flore d'un ruisseau de L'Ardenne belge. Mém. Mus. r. Hist. nat. Belg. 99, 3-177.

Conrad W. 1942b. Notes protistologiques, XXIV. Flagellates, Algues et Thécamébiens d'Ardenne. Bull. Mus. r. Hist. nat. Belg. 18 (29), 1-12.

Davidova R. 2003. Testacean fauna (Rhizopoda: Testacea) at Shumensko plateau (North-Eastern Bulgaria). Jubilee scientific conference dedicated to the $30^{\text {th }}$ anniversary of the founding of Shumen University. Univ. Publ. House, 36-42 (in Bulgarian with English summary).

Decloitre L. 1955. Speleologia Africana. Thécamoebiens de la grotte des Singes a Ségéa (Guinée). 
Bull. Inst. Français d'Afrique Noire. 17, 989-1019.

Deflandre G. 1936. Etude monographique sur le genre Nebela Leidy. Ann. Protistologie. 5, 201-286.

Foissner W. and Korganova G.A. 1995. Redescription of three testate amoebae (Protozoa, Rhizopoda) from a Caucasian soil: Centropyxis plagiostoma Bonnet and Thomas, Cyclopyxis kahli (Deflandre) and C. intermedia Kufferath. Arch. Protistenkd. 146, 13-28.

Gauthier-Lièvre L. 1953. Les genres Nebela, Paraquadrula and Pseudonebela (Rhizopodes testaces) en Afrique. Bull. Soc. Hist. Nat. Afrique du Nord. 43, 324-366.

Gauthier-Lièvre L. 1957. Additions aux Nebela d'Afrique 1957. Bull. Soc. Hist. Nat. Afrique du Nord. 48, 494-523.

Gauthier-Lièvre L. and Thomas R. 1961. Troisième note sur les Nebelinae d'Afrique. Bull. Soc. Hist. Nat. Afrique du Nord. 52, 41-48.

Gilbert D., Amblard C., Bourdier G. and Francez A.J. 1998. The microbial loop at the surface of a peatland: structure, functioning and impact of nutrients inputs. Microb. Ecol. 35, 89-93. https:// doi.org/10.1007/s002489900062

Godeanu S. 1981. Fauna de testacee din circul glaciar Bucura (Muntii Retezat) Ocrot. nat., med. inconj. 25 (2), 191-200 (in Romanian with French summary).

Golemansky V. 1962. Faune muscicole de Guinee forestiere (Rhizopodes Testaces). Recherches Africaines. 4, 33-60.

Golemansky V. 1965. Étude sur les espèces et l'écologie des rhizopodes (Rhizopoda, Testacea) des hautes tourbières de la montagne Vitocha. Ann. Univ. Sofia, Fac. Biol. 59 (1), 17-38 (in Bulgarian with Russian and French summaries).

Golemansky V. 1966. Étude de la faune rhizopodique (Rhizopoda, Testacea) dans le sol de la tourbiére de Sadovo, region de Plovdiv. In: Die Fauna Thrakiens, Band III. BAS, Sofia. 217-230 (in Bulgarian with French summary).

Golemansky V. 1967. Étude sur la faune de rhizopodes (Sarcodina, Rhizopoda) des mousses epiphytes et terricoles en Bulgarie. Bull. Inst. Zool. Mus., Sofia. 24, 103-119 (in Bulgarian with Russian and French summaries).

Golemansky V. 1968. On the species composition and distribution of the rhizopod fauna of upper Smolian Lakes. Bull. Inst. Zool. Mus., Sofia. 27, 171-187. (in Bulgarian with Russian and English summaries).

Golemansky V. 1974. La faune rhizopodique (Rhizopoda, Testacea) du littoral et du benthal du lac Popovo dans la montagne de Pirine. Bull. Inst. Zool. Mus., Sofia. 40, 47-58. (in Bulgarian with Russian and French summaries).

Golemansky V. and Todorov M. 1985. Comparative studies on the composition and distribution of the thecamoeban fauna (Rhizopoda, Testacea) in three types of soil in Vitosha Mountain. Acta Zool. Bulg. 29, 50-64 (in Bulgarian with Russian and English summaries).

Golemansky V. and Todorov M. 1990. Rhizopodic fauna (Protozoa, Rhizopoda) from Vitoša. In: Fauna of Southwestern Bulgaria, Part 3. BAS, Sofia, 19-48 (in Bulgarian with Russian and English summaries).

Golemansky V. and Todorov M. 1993. Testate amoebae (Protozoa, Rhizopoda) in the watercatchment area and littoral of the 'Beli Iskar' dam. Acta Zool. Bulg. 46, 3-9.

Golemansky V., Todorov M. and Temelkov B. 2006. Diversity and biotopic distribution of the Rhizopods (Rhizopoda: Lobosia and Filosia) from the Western Rhodopes (Bulgaria). In: Biodiversity of Bulgaria. 3. Biodiversity of Western Rhodopes (Bulgaria and Greece) (Ed: Beron P.). I. Pensoft and Nat. Mus. Natur. Hist., Sofia, 205-220.

Gracia M. del P. 1968. Nota sobre Nebela carinata (Archer.) Leidy (Thecamoeboidea). Publ. Inst. Biol. Apl. Barcelona. 44, 45-55.

Gracia M. del P. 1972. Contribuciyn al estudio de los tecamebas (Protozoa Thecamoeboidea). Publ. Inst. Biol. Apl. Barcelona. 52, 5-42.

Grospietsch T. 1982. Untersuchungen über die Thekamöbenfauna (Rhizopoda Testacea) im Murnauer Moos. Entomofauna Linz, suppl. 1, 57-88.

Hoogenraad H.R. and De Groot A.A. 1940a. Moosbewohnende thekamöbe Rhizopoden von Java und Sumatra. Treubia (Buitenzorg). 17, 209-259.

Hoogenraad H.R. and De Groot A.A. 1940b. Zoetwaterrhizopoden en heliozoën. In Fauna van Nederland (Ed.: Sijthoff A.W.). Fauna von Nederland. Aflerering. 9, 1-303.

Jassey V.E.J., Signarbieux C., Hattenschwiler S., Bragazza L., Buttler A., Delarue F., Fournier B., Gilbert D., Laggoun-Defarge F., Lara E., Mills R.T.E., Mitchell E.A.D., Payne R.J. and Robroek B.J.M. 2015. An unexpected role for mixotrophs in the response of peatland carbon cycling to climate warming. Scientific Reports. 5, 16931. https://doi. org/10.1038/srep16931

Kosakyan A., Heger T.J., Leander B.S., Todorov M., Mitchell E.A.D. and Lara E. 2012. COI barcoding of nebelid testate amoebae (Amoebozoa: 
Arcellinida): Extensive cryptic diversity and redefinition of the Hyalospheniidae Schultze. Protist. 163, 415-434. https://doi.org/10.1016/j.protis. 2011.10.003

Kosakyan A., Lahr D.J.G., Mulot M., Meisterfeld R., Mitchell E.A.D. and Lara E. 2016. Phylogenetic reconstruction based on COI reshuffles the taxonomy of hyalosphenid shelled (testate) amoebae and reveals the convoluted evolution of shell plate shapes. Cladistics. 32, 606-623. https:// doi.org/10.1111/cla.12167

Lamentowicz M. and Mitchell E.A.D. 2005. The ecology of testate amoebae (Protists) in Sphagnum in North-western Poland in relation to peatland ecology. Micr. Ecol. 50, 48-63. https:// doi.org/10.1007/s00248-004-0105-8.

Lamentowicz M., Gałka M., Milecka K., Tobolski K., Lamentowicz L., Fiałkiewicz-Kozieł B. and Blaauw M. 2013. A 1300-year multi-proxy, high-resolution record from a rich fen in northern Poland: reconstructing hydrology, land use and climate change. J. Quat. Sci. 28, 582-594. https:// doi.org/10.1002/jqs. 2650

Luketa S. 2017. Taxonomy of Quadrulella longicollis and Q. symmetrica (Arcellinida: Hyalospheniidae) from the central part of the Balkan Peninsula. Protistology. 11, 215-230. https://doi. org/10.21685/1680-0826-2017-11-4-3

Marcisz K., Tinner W., Colombaroli D., Kołaczek P., Słowinski M., Fiałkiewicz-Kozieł B., Łokas E. and Lamentowicz M. 2015. Longterm hydrological dynamics and fire history over the last 2000 years in CE Europe reconstructed from a high-resolut on peat archive. Quat. Sci. Rev. 112, 138-152. https://doi.org/10.1016/j. quascirev.2015.01.019

Marcisz K., Jassey V.E.J., Kosakyan A., Krashevska V., Lahr D.J.G., Lara E., Lamentowicz Ł., Lamentowicz M., MacumberA., Mazei Y., Mitchell E.A.D., Nasser N.A. and Patterson R.T. 2020. Testate amoeba functional traits and their use in Paleoecology. Front. Ecol. Evol. 8,575966. https:// doi.org/10.3389/fevo.2020.575966

Meyer C., Gilbert D., Gillet F., Moskura M., Franchi M. and Bernard N. 2012. Using "bryophytes and their associated testate amoeba" microsystems as indicators of atmospheric pollution. Ecol. Indic. 13, 144-151. https://doi.org/10.1016/j. ecolind.2011.05.020

Mitchell E.A.D., Charman D.J. and Warner B.G. 2008a. Testate amoebae analysis in ecological and paleoecological studies of wetlands: past, present and future. Biodivers. Conserv. 17, 2115-2137. https://doi.org/10.1007/s10531-007-9221-3

Mitchell E.A.D., Payne R.J. and Lamentowicz M. 2008b. Potential implications of differential preservation of testate amoeba shells for paleoenvironmental reconstruction in peatlands. J. Paleolimnol. 40, 603-618. https://doi.org/10.1007/ s10933-007-9185-z

Pateff P. 1924. Kenntnis der Süsswasserrhizopoden von Bulgarien. Arb. Bulg. Nat. Ges. 11, 1-46 (in Bulgarian with German summary).

Patterson R.T., Lamoureux E.D.R., Neville L.A. and Macumber A.L. 2013. Arcellacea (Testate Lobose Amoebae) as $\mathrm{pH}$ indicators in a pyrite mineacidified Lake, Northeastern Ontario, Canada. Microb. Ecol. 65, 541-554. https://doi. org/10.1007/s00248-012-0108-9

Payne R.J., Bobrov A.A., Tsyganov A.N., Babeshko K.V., SloanT.J., Kay M., Kupriyanov D.A., Surkov N.V., Novenko E.Y., Andreev A.A. and Mazei Y.A. 2021. First records of contemporary testate amoeba assemblages from the Kamchatka Peninsula, Russia and potential for palaeoenvironmental reconstruction. Boreas. 50. https:// doi.org/10.1111/bor.12469

Payne R.J., Telford R.J., Blackford J.J., Blundell A., Booth R.K., Charman D.J., Lamentowicz L., Lamentowicz M., Mitchell E.A.D., Potts G., Swindles G.T., Warner B.G. and Woodland W. 2012. Testing peatland testate amoeba transfer functions: appropriate methods for clustered training-sets. The Holocene. 22, 819-825. https://doi. org/10.1177/0959683611430412

Pérez-Juárez H., Serrano-Vázquez A., Kosakyan A., Mitchell E.A.D., Aguilar V.M., Lahr D.J., Moreno M.M., Cuellar H.M., Eguiarte L.E. and Lara E. 2017. Quadrulella texcalense sp. nov. from a Mexican desert: an unexpected new environment for hyalospheniid testate amoebae. Eur. J. Protistol. 61, 253-264. https://doi.org/10. 1016/j.ejop.2017.06.008

Swindles G.T., Amesbury M.J., Turner T.E., Carrivick J.L., Woulds C., Raby C., Mullan D., Roland T.P., Galloway J.M., Parry L., Kokfelt U., Garneau M., Charman D.J. and Holden J. 2015. Evaluating the use of testate amoebae for palaeohydrological reconstruction in permafrost peat-lands. Palaeogeogr. Palaeoclimatol. Palaeoecol. 424, 111-122. https://doi.org/10.1016/j. palaeo.2015.02.004

Taranek K.J. 1882. Monographie der Nebeliden Böhmens. Ein Beitrag zur Kenntniss der Süsswasser- 
Monothalamien. Abh. Königl. Böhm. Ges. Wiss. 2, 1-56.

Todorov M. 1993. Testate Amoebae (Protozoa, Rhizopoda) in soils of Vitoša Mountain (Bulgaria). Acta Zool. Bulg. 46, 16-23.

Todorov M. 2004. Testate amoebae (Protozoa, Rhizopoda) of the Ribni Ezera Glacial Lakes in the Rila Mountains (South-West Bulgaria). Acta Zool. Bulg. 56 (3), 243-252.

Todorov M. 2005. Testate amoebae (Protozoa, Rhizopoda) of the glacial lakes Smradlivo ezero in the Rila National Park (Southwestern Bulgaria). Acta Zool. Bulg. 57 (1), 13-23.

Todorov M. and Bankov N. 2019. An atlas of Sphagnum-dwelling testate amoebae in Bulgaria. Pensoft, Sofia. https://doi.org/10.3897/ab.e38685

Todorov M. and Golemansky V. 1995. Ecological characteristics of soil Testacea (Protozoa, Rhizopoda) of Vitoša Mountain (Bulgaria). Acta Zool. Bulg. 48, 3-22.

Todorov M. and Golemansky V. 2000. Testate amoebae (Protozoa: Testacea) of the glacial lakes in the Rila National Park (Southwestern Bulgaria). In: Biodiversity and Evolution of Glacial Water Ecosystems in the Rila Mountains (Eds: Golemansky V. and Naidenow W.). Prof. Marin Drinov Acad. Publ. House, Sofia, 15-26.

Todorov M., Golemansky V. and Temelkov B. 2008. Diversity and biotopic distribution of testate amoebae (Protozoa: Arcellinida and Euglyphida) in the Batak Reservoir (Southern Bulgaria). Acta Zool. Bulg. 60 (2), 115-124.
Tsyganov A.N. and Mazei Yu.A. 2006. Morphology and biometry of Arcella intermedia (Deflandre, 1928) nov. comb. from Russia and review of hemispheric species of the genus Arcella (Testacealobosea: Arcellinida). Protistology. 4 (4), 361369.

Turner T.E., Swindles G.T., Charman D.J. and Blundell A. 2013. Comparing regional and supraregional transfer functions for palaeohydrological reconstruction from Holocene peatlands. Palaeogeogr. Palaeoclimatol. Palaeoecol. 369, 395-408. http://dx.doi.org/10.1016/j.palaeo.2012.11.005

Valkanov A. 1932. Notizen über das Leben bulgarischer Hochgebirgsseen. Arb. Bulg. Nat. Ges. Sofia. 15-16, 207-226 (in Bulgarian with German summary).

Vucetich M.C. 1983. Contribution al conocimento del genero Quadrulella Cockerell, 1909 (Rhizopoda, Testaceolobosa) en la Argentina. Limnobios. 2, 526-535.

Vucetich M.C. and Lopretto E.C. 1995. Rhizopoda: Amebas Testaceas. Fauna de Aqua Dulce de la Republica Argentina. 3, 5-44.

Walker I. 1982. The thecamoebae (Protozoa, Rhizopoda) of small Amazonian forest streams and their possible use as indicator organisms for water quality. Acta Amazonica. 12, 79-105.

Wallich G.C. 1863. Further observations on the distinctive characters, habits, and reproductive phenomena of the amoeban Rhizopods. Ann. Mag. Nat. Hist. 12, 448-468.

Address for correspondence: Milcho Todorov, Institute of Biodiversity and Ecosystem Research, Bulgarian Academy of Sciences, 1 Tsar Osvoboditel Blvd., 1000 Sofia, Bulgaria; e-mail: todorovmilcho@gmail.com 